\title{
Decreased Serum Factor B Concentration Associated with Decreased Opsonization of Escherichia coli in the Idiopathic Nephrotic Syndrome
}

\author{
ROBERT H. McLEAN
}

University of Connecticut Health Center, Department of Pediatrics, Farmington, Connecticut, USA

ARNE FORSGREN

Lunds University, Institution for Clinical Bacteriology, Mälmo Allmanna Skukhus, Mälmo, Sweden

BENGT BJÖRKSTÉN

Department of Pediatrics, University Hospital of Umed, Umed, Sweden

Y. KIM, PAUL G. QUIE, AND ALFRED F. MICHAEL

University of Minnesota Medical School, Department of Pediatrics, Minneapolis, Minnesota, USA

\section{Summary}

We report correlative studies of factor $\mathrm{B}$, properdin, $\mathrm{C3}$, and the serum opsonic activity for Escherichia coli and Staphylococcus aureus in patients with the idiopathic nephrotic syndrome (INS). Thirty-two patients with the idiopathic nephrotic syndrome were studied. Twenty-two patients were steroid responsive (Group $I$ ), of which 11 patients were steroid dependent. Ten patients were steroid resistant (Group $I I)$.

The presence of the nephrotic syndrome (regardless of steroid responsiveness) was associated with a significantly reduced mean serum factor B concentration. Of the complement components studied, only factor $B$ was significantly decreased during relapse (factor B $24.8 \pm 9 \mu \mathrm{g} \mathrm{N} / \mathrm{ml}$ in INS versus $46 \pm 12 \mu \mathrm{g} / \mathrm{ml}$ in normal, $P<0.001)$. When the combined groups were studied during remission of INS, the mean serum factor B concentrations were not different from normal. Similar results were found when each group was examined separately. Ten patients had serum factor $B$ determinations during both exacerbation and remission of the nephrotic syndrome. The serum factor $B$ increased in nine patients and was unchanged in one. A highly positive correlation between serum factor $B$ and serum albumin concentrations was present $(r=+0.805, P<0.001)$.

Twenty sera from 14 patients with the nephrotic syndrome, studied at various stages of the nephrotic syndrome, were evaluated for opsonization titers of $E$. coli employing the bacterial killing assay. Eleven sera from seven patients had reduced capacity for $E$. coli opsonization, i.e., bacteria were not opsonized in $2 \%$ serum. There was a significant difference between the mean factor $B$ concentrations of sera with abnormal as compared to normal opsonization of $E$. coli $(P<\mathbf{0 . 0 0 1})$. The serum of one patient with nephrosis opsonized $E$. coli normally $60 \mathrm{~min}$ after the addition of isolated factor $B$. The opsonic activity of serums from three additional patients with relapse of INS were studied by determining uptake of radiolabeled $E$. coli by normal leukocytes. The addition of isolated factor $B$ increased phagocytosis in the serum from two of three patients. Decreased opsonization of $S$. aureus was found in only 3 (two patients) of 19 sera. The complement components, C1q, C4, properdin, and C3, were normal during both periods of exacerbation and remission with the exception that $\mathrm{C} 4$ was significantly elevated during remission of nephrosis.

These results suggest that a significant decrease of serum factor $B$ concentration is associated with abnormal opsonization of $E$. coli. We do not know the cause of decreased serum factor $B$, but renal pathologic findings do not appear to be of etiologic importance. The high correlation of serum factor B with serum albumin concentration suggests that factor $B$, with a molecular weight of 80,000 , was being lost in the urine.

\section{Speculation}

The increased incidence of severe infections such as peritonitis, which occurs in INS patients, may be the result of reduced serum factor B, a component of the alternative pathway. Although further work is necessary to determine the cause of factor $B$ decrease in INS and the role of other serum factors in this opsonic defect, the understanding of the role of factor $B$ in the predilection of nephrotic patients to certain infections could be of great importance in the care of these patients.

An increased incidence of infection due particularly to Diplococcus pneumoniae and $E$. coli has been noted in patients with the INS $(3,5)$. Previous studies of this increased susceptibility to infection have focused on aberrations of phagocytosis, but the etiology of these infections remains undefined $(7,19)$.

IVe have previously noted decreased serum concentration of the alternative pathway protein factor $B$ in the idiopathic nephrotic syndrome (18). The alternative pathway of complement (C) activation includes several normal human serum proteins which result in activation of $\mathrm{C} 3$ by an enzyme which is not $\mathrm{C} 42$ $(10,16,22)$. Factor $B$ (also known as glycine-rich $\beta$-glycoprotein or $\mathrm{C} 3$ proactivator) is one component of the alternative pathway (10), and has also been shown to be a component of the serum heat-labile opsonin system (12). Heat-labile opsonins do not have immunologic specificity and appear to be particularly important in immunologically inexperienced animals lacking im- 
mune antibody against certain microorganisms (28, 29). Depressed alternative pathway factors have been found in newborns (27) and abnomalities of alternative pathway factors and depressed opsonic capacity for pneumococci were found in patients with sickle cell anemia (14).

We report correlative studies of serum concentrations of factor B, properdin, C3, and serum opsonic activity for $E$. coli and $S$. aureus in patients with the idiopathic nephrotic syndrome.

\section{MATERIALS AND METHODS}

\section{PATIENTS}

Thirty-two patients with the idiopathic nephrotic syndrome at the University of Minnesota Hospitals were studied. Informed consent to perform the studies reported was obtained from all patients. Patients with evidence of systemic disease which might cause the nephrotic syndrome were excluded from this study. Patients (12 females, 20 males) ranged in ages from 0.5-66 years. The diagnosis of the nephrotic syndrome or exacerbation of nephrotic syndrome was malde in patients with proteinuria, hypoalbuminemia, and edema. Remission of INS was defined as loss of edema and proteinuria (less than $100 \mathrm{mg}$ protein $/ 24 \mathrm{hr}$ ) and return of serum albumin to $3 \mathrm{~g} / 100 \mathrm{ml}$ or more.

Twenty-two patients (group I) were steroid responsive, of which 11 patients were steroid dependent. Ten patients (group II) were steroid resistant. Patients with steroid-responsive INS were those losing all findings of nephrosis after steroid therapy (prednisone $60 \mathrm{mg} / \mathrm{m}^{2} /$ day). Steroid-dependent patients were those experiencing recurrent signs of nephrosis after tapering or cessation of steroid therapy. Steroid-resistant patients did not respond to steroid therapy; however, three patients from this group gradually lost all findings of the neplurotic state except for low grade proteinuria and were, therefore, defined as in remission. Twenty-eight of the 32 patients had at least one renal biopsy. In group $l, 9$ of the is patients biopsied had normal biopsies ("nil lesion"), t had minimal mesangial hypercellularity, 3 had mesangial hyperecllularity and focal sclerosis, and 2 had focal sclerosis. In group $I I, 1$ patient had a normal biopsy; the remaining 9 patients had focal sclerosis and mesangial hypercellularity.

\section{IMMIUNODIFFUSION ASSAYS OF FACTOR B, C3, AND PROPERDIN}

Immunodiffusion assays of factor B, C3, and properdin were performed as previously described (17). Properdin and factor B assays were performed only on sera kept at $-70^{\circ}$. $\mathrm{C} 3$ measurements were performed on sera incubated at $37^{\circ}$ for 3-7 day's (with sodium azide $0.02 \%$ ) in order to measure consistently the antigenic site $\mathrm{C} 3 \mathrm{c}$ on the aged molecule of $\mathrm{C} 3$. Duplicate serial dilutions of a reference serum of known concentration were placed on each plate to construct a standard curve of area against zoncentration. The normal values for C3, factor B, and properdin are given in Table 1 . The reproducibility of these assays has been reported previously (17).

\section{MMIUNODIFIUSION ASSAYS OF ALBUMIN, Ct, AND ClY}

Monospecific goat anti-human C4 (Meloy Laboratories, Inc., Springfield, Va.), was diluted $1 / 50$ in $1 \%$ agarose in immunodifusion plates prepared in the same manner as for C3. This antiserum produced a single precipitin line by double diffusion in agarose against normal human serum. Results were expressed as 1 percentage of a reference serum with a day-to-day variation six times) of a single serum being $171 \pm 15 \%$ (1 SD) reference.

Cly was isolated as described previously (21). Monospecific abbit anti-human $\mathrm{Cl}$ q was prepared by multiple subcutaneous njection of isolated $\mathrm{Cla}$ in complete Freund's adjuvant and mmunodiffusion plates prepared as described for C3. A single srecipitin line was found by double diffusion of this rabbit antiuuman $\mathrm{Cl}$ g antiserum against normal human serum. A standard reference serum for $\mathrm{Cl}$, kindly quantitated by Dr. R. Stroud, was placed in duplicate on each immunodiffusion plate. Day-today measurement (15 times) of a single serum was $106+9 \mu \mathrm{g} /$ $\mathrm{ml}(1 \mathrm{SD})$.

Human serum albumin (Schwartz-Mann, Orangeburg, N. J.) was further purified over Bio-Gel A $1.5 \mathrm{M}$ (Bio-Rad Laboratories, Richmond, Calif.). The pool of aliquots from the peak of the protein eluate, in complete Freund's adjuvant, was injected subcutaneously into rabbits on several occasions. This monospecific antiserum, as determined by double diffusion in agarose and by immunoelectrophoresis against normal human serum, was used in a $1 / 20$ dilution to prepare immunodiffusion plates as described for C3. A serial dilution of a reference serum (albumin quantitated in the clinical chemistry laboratories of the University of Minnesota Jospitals) was placed on each immunodiffusion plate for construction of the standard curve.

\section{PHAGOCYTOSIS ASSAYS FOR MEASURING SERUN OPSONIC ACTIVITY}

Polymorphonuclear leukocytes (PMN's) were separated from venous blood from healthy adult donors by methods previously described (24).

Sera from patients were kept frozen at $-70^{\circ}$ until used for phagocytosis assays. Only one patient (patient $I$. Table 2) was receiving antibiotics when studied. Control serum consisted of sera pooled from five healthy adult blood donors, divided into 1 $\mathrm{ml}$ aliquots, and kept frozen at $-70^{\circ}$ until used.

$S$. aureus 502A, E. coli K12, and E. coli 022:H16 were used as test organisms. The $S$. aureus strain activated complement via the classic pathway and the two $E$. coli strains activated complement via the alternative pathway. Neither the $S$. aureus or $E$. coli strains were susceptible to bactericidal activity of fresh serum at $20 \%$ concentration. The bacteria were cultured for $16-18 \mathrm{hr}$ in Trypticase soy broth and after washing in sterile saline, adjusted to a concentration of $5 \times 10^{7}$ bacteria/ $/ \mathrm{ml}$. The E. coli $022: 1116$ strain was used for assays measuring phagocytosis of radiolabeled bacteria.

Phagocytosis assays were performed with modification of the Maalse method described by Quie at al. (24). Polymorphomuclear leukocytes $\left(5 \times 10^{6}\right.$ PMN's $)$ in a volume of $0.5 \mathrm{ml}$ were mixed with $0.4 \mathrm{ml}$ whole serum dilutions or serum fractions, and $0.1 \mathrm{ml}$ bacterial suspension in a medium of Hanks' balaneed salt solution with $0.1 \%$ gelatin (gel-Hanks' solution). The final ratio of PMN's to bacteria in the phagocytic mixture was approximately $1: 1$. The phagocytic mixtures were tumbled end-over-end at $37^{\circ}$ at $10 \mathrm{rpm}$ on a Rotorack and samples were drawn for viable bacterial counts at $0,30,60$, and $120 \mathrm{~min}$. Serial 2-fold dilutions of the test sera were made with I Janks' balaneed salt solution containing calcium at $1.26 \mathrm{mM} /$ liter and magnesium at (0.09 $\mathrm{mM}$ /liter. Normal serum opsonization was recorded when there was a reduction of bacteria from approximately $5 \times 10^{1 \mathrm{i}}$ bacteria $/ \mathrm{ml}$ at zero time to less than $1 \times 10^{6}$ bacteria after 120 min of incubation. In each experiment the serum from a patient with nephrotic syndrome was compared with a sample of the control serum pool at a similar concentration.

Fifteen normal sera (mean factor B $36.7 \pm 8.5 \mu \mathrm{g} \mathrm{N} / \mathrm{ml}$ ) were analyzed, and in all 15 there was a reduction from $5 \times 10^{\text {i }}$ bacteria to less than $1 \times 10^{6}$ bacteria after $120 \mathrm{~min}$ in a serum concentration of $1 \%$ and 2 in a concentration of $2 \%$ or less. Consequently, opsonic activity was considered decreased in patient sera when more than $2 \%$ was needed for reduction of colony counts to less than $1 \times 10^{4}$ bacteria (less than $80 \%$ of the initial inoculum).

In several experiments, leukocytes were separated from supernatant fluid by centrifugation at $50 \times \mathrm{g}$ after 60 and 12() $\mathrm{min}$ of incubation. The bacteria in the supernatant fluid and bacteria in the leukocyte cell pellet were counted after lysis of the leukocytes in distilled water. The $S$. aureus $502 \mathrm{~A}$ and both $E$. coli strains were killed rapidly by normal human neutrophils after phagocytosis. Although the endpoint of the assay measured 
intracellular killing of bacteria by leukocytes, there was such rapid and uniform bactericidal activity that the bacterial count was an accurate assessment of phagocytosis. There was no phagocytosis or killing of $S$. aureus or $E$. coli when incubated with leukocytes in the absence of serum or serum factors.

An assay system utilizing radiolabeled $E$. coli was also utilized for measuring phagocytosis (20). E. coli strain (022:h16) was used as the test organism. The bacteria were cultured in MuellerHinton broth containing $2 \mu \mathrm{Ci}$ of $\left[{ }^{3} \mathrm{H}\right]$-thymidine/ml (specific activity $6.7 \mathrm{Ci} / \mathrm{mM}$ ). After a 12-16-hr incubation, the bacteria was washed three times in Hanks' BSS. Labeling efficiency was approximately 1 count/min/60)-1,200 bacteria. The bacteria strain associated radioactivity was more than $97 \%$ of the total in washed bacteria suspensions. About $5 \times 10^{7}$ bacteria were opsonized at $37^{\circ}$ in $0.4 \mathrm{ml} 10 \%$ serum or $10 \%$ serum reconstituted with factor $B$. After $30 \mathrm{~min}$ of incubation, $5 \times 10^{6}$ PMN's were added to the suspension, giving a final bacteria $P M N$ ratio of 10:1. The phagocytosis mixtures were tumbled at $10 \mathrm{rpm}$ in a $37^{\circ}$ incubator, and after $10 \mathrm{~min}$ and $20 \mathrm{~min} 0.1-\mathrm{ml}$ samples were centrifuged at $160 \times g$ for 5 min. The leukocyte pellets were washed twice in PBS and then solubilized in BioSolv (Beckman Instruments, Chicago, Ill.).

To measure the total bacteria-associated radioactivity after 20 min of incubation, $100-\mu \mathrm{Ci}$ samples were added to PMN's. These samples were centrifuged at $1,600 \times \mathrm{g}$ for $15 \mathrm{~min}$, and the bacterial pellet was then solubilized in BioSolv. Radioactivity was counted in a Beckman LS250 scintillation counter. The ingestion in each sample at 2, 10 , and $20 \mathrm{~min}$ was calculated as follows: $\%$ ingestion $=\mathrm{cmp}$ of leukocyte $\mathrm{pellet} / \mathrm{cpm}$ of bacterial pellet. In parallel experiments with lysostaphin there was no loss of leukocyte-associated radioactivity. This was evidence that the staphylococcal organism was engulfed and not simply adherent.

The uptake of bacteria opsonized in different sera were compared to and expressed as a percentage of the ingestion of bacteria opsonized in $5 \%$ pooled human serum using the same serum pool in all experiments.

Factor B was added to selected sera with low levels of factor B and was isolated from pooled human serum by the method of Götze and Müller-Eberhard (10). This factor B showed a single precipitin line in the $\beta$ region when examined by immunoelectrophoresis utilizing a monospecific antiserum for factor $B$. Functional integrity of factor $B$ was present as determined by a zymosan hemolytic assay (9). IgG (Cohn fraction II (Red Cross) following passage of DEAE) was also studied in reconstitution experiments.

\section{RESULTS}

\section{SERUM FACTOR B CONCENTRATION IN INS}

The presence of the nephrotic syndrome (regardless of steroid responsiveness) was associated with a significantly reduced mean serum factor $B$ concentration. When patients were divided according to steroid responsiveness, 16 patients of group 1 (steroid responsive) and 8 patients of group $I I$ (steroid nonresponsive) were studied during exacerbation of the nephrotic syndrome. Factor B levels of the combined groups $I$ and $I I$ are shown in Table 1. Of the complement components studied, only factor B was significantly decreased during relapse (factor $\mathrm{B}: 24.8 \pm 9 \mu \mathrm{g}$ $\mathrm{N} / \mathrm{ml}$ in INS versus $46 \pm 12 \mu \mathrm{g} \mathrm{N} / \mathrm{ml}$ in normal, $P<0.001)$. When the combined groups were studied during remission of INS, the mean serum factor $B$ concentrations were not different from normal (Table 1). The mean factor B levels of group I (24 $\pm 9 \mu \mathrm{g} \mathrm{N} / \mathrm{ml})$ and group $/ l(27 \pm 10 \mu \mathrm{g} \mathrm{N} / \mathrm{ml})$ were also each significantly lower than the controls $(P<0.001)$, but normal during remission (group $I: 45 \pm 15 \mu \mathrm{g} \mathrm{N} / \mathrm{ml}$; group $I I: 45 \pm 5$ $\mu \mathrm{g} \mathrm{N} / \mathrm{ml}$ ).

Ten patients had serum factor B determinations during both exacerbation and remission of the nephrotic syndrome. The serum factor $B$ increased in nine patients and was unchanged in one (Fig. 1).

A highly positive correlation between serum factor $B$ and serum albumin concentrations was present (Figure 2 ). Thirty sera representing a wide variation in factor $B$ concentrations were assayed for albumin concentrations (24 group $I$ sera, 6 group II sera). Regression analysis showed an $r$ value of +0.805 $(P<0.001)$ between the serum factor $B$ and albumin concentration.

Sera was available from a patient during a time when an infectious process was present. One patient had the congenital nephrotic syndrome, developed $D$. pne'umoniae septicemia, and meningitis when the serum factor B level was $8-12 \mu \mathrm{g} \mathrm{N} / \mathrm{ml}$. The opsonization assay for $E$. coli was reduced in this patient at the time of these infections (Table 2).

\section{RELATIONSHIP OF SERUM FACTOR B CONCENTRATION TO OPSONIZATION OF E. COLI}

Twenty sera from 14 patients with the nephrotic syndrome, studied at various stages of the nephrotic syndrome, were evaluated for opsonization titers of $E$. coli employing the bacterial killing assay. Eleven sera from seven patients had reduced capacity for $E$. coli opsonization; i.e., bacteria was not opsonized in $2 \%$ serum. With one exception, the serum factor B concentration of all of these eleven sera fell below the normal range (Table 2).

The mean serum factor $B$ concentrations of nephrotic sera with normal $E$. coli opsonization was normal in eight out of nine sera. There was a significant difference between the mean factor $B$ concentrations of sera with abnormal as compared to normal opsonization of $E$. coli $(P<0.001)$, but there were no significant differences in serum C3 or properdin concentrations (Table 2).

As noted in Figure 3, the serum of one patient with nephrosis opsonized $E$. coli normally after the addition of factor $B$ in both a crude and pure form. Factor $B$ without serum was ineffective. Factor $B$ did not reconstitute normal opsonization to the serum in the one patient with congenital nephrotic syndrome and did not increase opsonic capacity of normal serum.

The opsonic activity of serums from three additional patients

Table 1. Serum concentration of components of classic and alternative pathways during exacerbation and remission of idiopathic nephrotic syndrome (INS)

\begin{tabular}{lccccc}
\hline & $\mathrm{Clq}, \mu \mathrm{g} / \mathrm{ml}$ & $\mathrm{C} 4, \%$ reference & $\mathrm{C}, \mathrm{mg} / 100 \mathrm{ml}$ & $\begin{array}{c}\text { Properdin, \% } \\
\text { reference }\end{array}$ & $\begin{array}{c}\text { Factor B, } \\
\mu \mathrm{g} \mathrm{N} / \mathrm{ml}\end{array}$ \\
\hline $\begin{array}{l}\text { INS exacerbation } \\
\text { INS remission }\end{array}$ & $98 \pm 16^{\prime}(25)^{3}$ & $230 \pm 180(20)$ & $154 \pm 21.9(24)$ & $119 \pm 35(23)$ & $24.8 \pm 92(24)$ \\
Normal & $100 \pm 20(16)$ & $264 \pm 103^{\circ}(13)$ & $164 \pm 40(18)$ & $101 \pm 21(16)$ & $46.4 \pm 14(18)$ \\
\hline
\end{tabular}

$1 \pm 1$ SD.

2 Significantly different from normal by $P<0.001$ (Student's $t$-test).

${ }^{3}$ Numbers in parentheses are number of patients studied.

+ Significantly different from normal by $P<0.02$ (Student's $t$-test). 


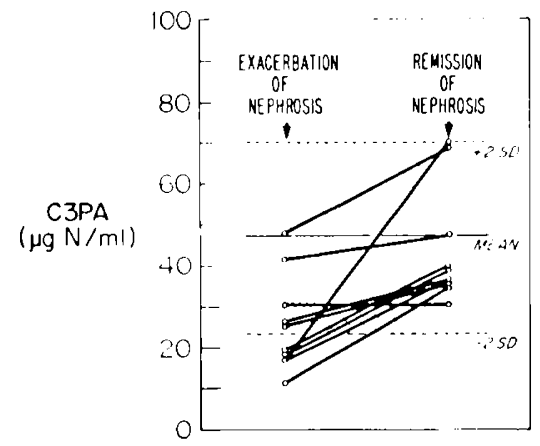

Fig. 1. Serum factor B (C3PA) concentration in 10 patients during periods of exacerbation and remission of idiopathic nephrotic syndrome. Normal serum factor $B$ range $( \pm 2$ SD) in shaded areas.

with relapse of nephrosis were studied by determining uptake of radiolabeled $E$. coli by normal leukocytes. Complement component concentrations of the patients sera and serum opsonic activities are shown in Table 3 . There was depressed opsonic activity in the serum of two patients and the addition of isolated factor $B$ increased phagocytosis in the serum from these two patients. The third patient had low serum factor B levels but normal opsonic activity. There was no increased opsonic activity after addition of factor $B$ to this patient's serum. Added factor $B$ also failed to increase opsonic activity of normal serum (Table 3).

The addition of IgG to a serum which had reduced serum factor $\mathrm{B}(10 \mu \mathrm{g} \mathrm{N} / \mathrm{ml})$ and reduced opsonization of $E$. coli did not increase phagocytosis of $E$. coli. However, the addition of factor $B$ to this serum increased phagocytosis towards, although not completely to, normal.

\section{RELATIONSHIP OF SERUM FACTOR B CONCENTRATION TO OPSONIZATION OF $S$. AUREUS}

Nineteen of the 20 sera studied for $E$. coli opsonization were also studied for opsonization of $S$. aureus. Decreased opsonization of $S$. aureus was found in only 3 (two patients) of 19 sera. The three sera with abnormal opsonization of $S$. aureus had markedly reduced serum levels of factor B $(14,8$, and $14 \mu \mathrm{g} \mathrm{N} /$ $\mathrm{ml})$. The sera with normal opsonization had a mean serum factor B concentration $(24.5 \pm 10.8 \mu \mathrm{g} \mathrm{N} / \mathrm{ml})$, which was significantly decreased from normal $(P<0.001)$. Serum concentration of $\mathrm{C} 3$ and properdin in these sera studied for $S$. atureus opsonization were not significantly different from a normal population.

\section{SERUM Clq, C4, C3, AND PROPERDIN CONCENTRATIONS IN INS}

The complement components $\mathrm{Cla}, \mathrm{C} 4$, properdin, and $\mathrm{C} 3$ were normal during both periods of exacerbation and remission, with the exception that C4 was significantly elevated during remission of nephrosis. The mean serum properdin concentration was also normal in nephrotic patients in remission and exacerbation (Table 1).

\section{DISCUSSION}

In this report we have extended our previous observation that serum factor $B$ levels are significantly lower during exacerbation of the INS (18). This serum abnormality may be related to defects in serum opsonization of bacteria. Our experimental results can be summarized as follows. ( 1 ) Serum factor $B$ is low during relapse of the idiopathic nephrotic syndrome and returns to normal levels during remission; serum factor $B$ correlates highly with serum albumin. (2) Serum opsonization, as assessed by two methods for determining phagocytosis of $E$. coli, is reduced in nephrotic sera with the lowest serum factor B concentration. Opsonization of $S$. aureus is normal in most nephrotic sera. (3) Reconstitution of nephrotic sera with highly purified factor $B$ results in increased opsonization (i.e., there is increased phagocytosis) during the initial $60 \mathrm{~min}$ of incubation in three of five patients.

In the idiopathic nephrotic syndrome, classic serum C components have been found to be present in normal concentrations, with the exception of occasionally decreased $\mathrm{Clq}(8,15)$. In this report, significantly decreased factor $B$ concentrations are found in sera of patients with exacerbation of INS in which there was no significant reduction in concentration of the classic $\mathrm{C}$ components $\mathrm{C} 1 \mathrm{q}, \mathrm{C} 4$, or $\mathrm{C} 3$. Because of this specific decrease in serum factor $B$, it was possible to evaluate the role of this alternative pathway protein in the opsonization of certain organisms.

The mean factor B concentration of sera from INS patients which have abnormal opsonization of $E$. coli is significantly reduced from normal. There is overlap of factor $B$ values between those sera with normal opsonization in comparison with those with abnormal opsonization. Nevertheless, a significant difference is found between the mean serum concentration of factor $B$ of these groups. These results suggest that a significant decrease of serum factor $B$ concentration is associated with abnormal opsonization of $E$. coli.

Data supporting the importance of factor $B$ for normal opsonization of $E$. coli is provided by the reconstitution of opsonization to normal by the addition of isolated factor $B$ to three sera with deficient factor B and deficient opsonization (Fig. 3, Table 3).

Opsonization of encapsulated bacteria is necessary for efficient phagocytosis. Serum opsonins in man include immunoglobulin ( $\operatorname{IgG}$ and $\operatorname{IgM})(23,25)$, the first four components of complement $(\mathrm{C} 1, \mathrm{C} 4, \mathrm{C} 2, \mathrm{C} 3)$, and the heat-labile opsonin system $(11,13,26)$. Since $\mathrm{C} 4$-deficient guinea pigs opsonized pneumococcus normally, it has been suggested that the C3cleaving enzyme might be equivalent to factor B (29). Studies with $\mathrm{Cl}$ a and immunoglobulin ( $\mathrm{IgG}$, IgM, IgA)-deficient human sera demonstrated no requirement for these proteins for normal opsonization of $E$. coli 075 . However, as confirmed by our studies, the addition of factor $B$ to heat-inactivated serum was shown to restore normal opsonization of $E$. coli (11). Thus, C3 appears to be the pivotal protein in the complement cascade and activation of $\mathrm{C} 3$ by the classic or alternative pathway leads to release of biologically active proteins. Studies of patients with acquired and congenital $C$ deficiencies have also focused attention on the importance of the alternative pathway of $\mathrm{C}$ for adequate antimicrobial defense. In vitro abnormalities of bacte-

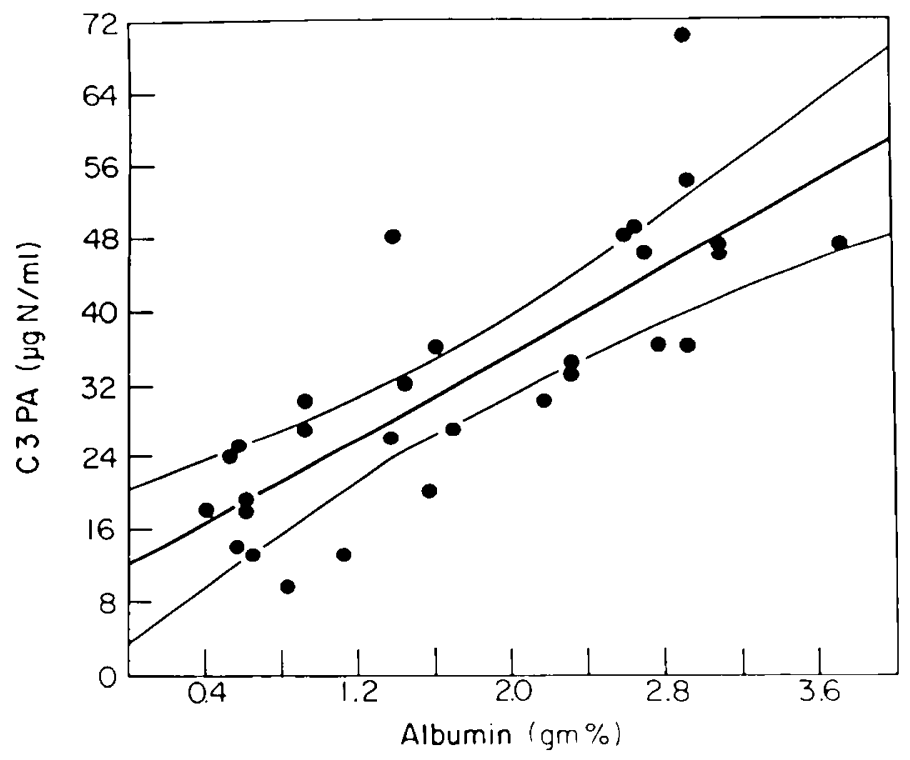

Fig. 2. Serum factor B(C3PA) versus albumin: measurements were made on the same sera. The correlation coefficient for the regression line was +0.805 , with the $95 \%$ confidence limits indicated by curved lines $(P$ $<0.001)$. 
Table 2. Relationship of serum factor B, C3, and properdin to phagocytosis of Escherichia coli in idiopathic nephrotic syndrome

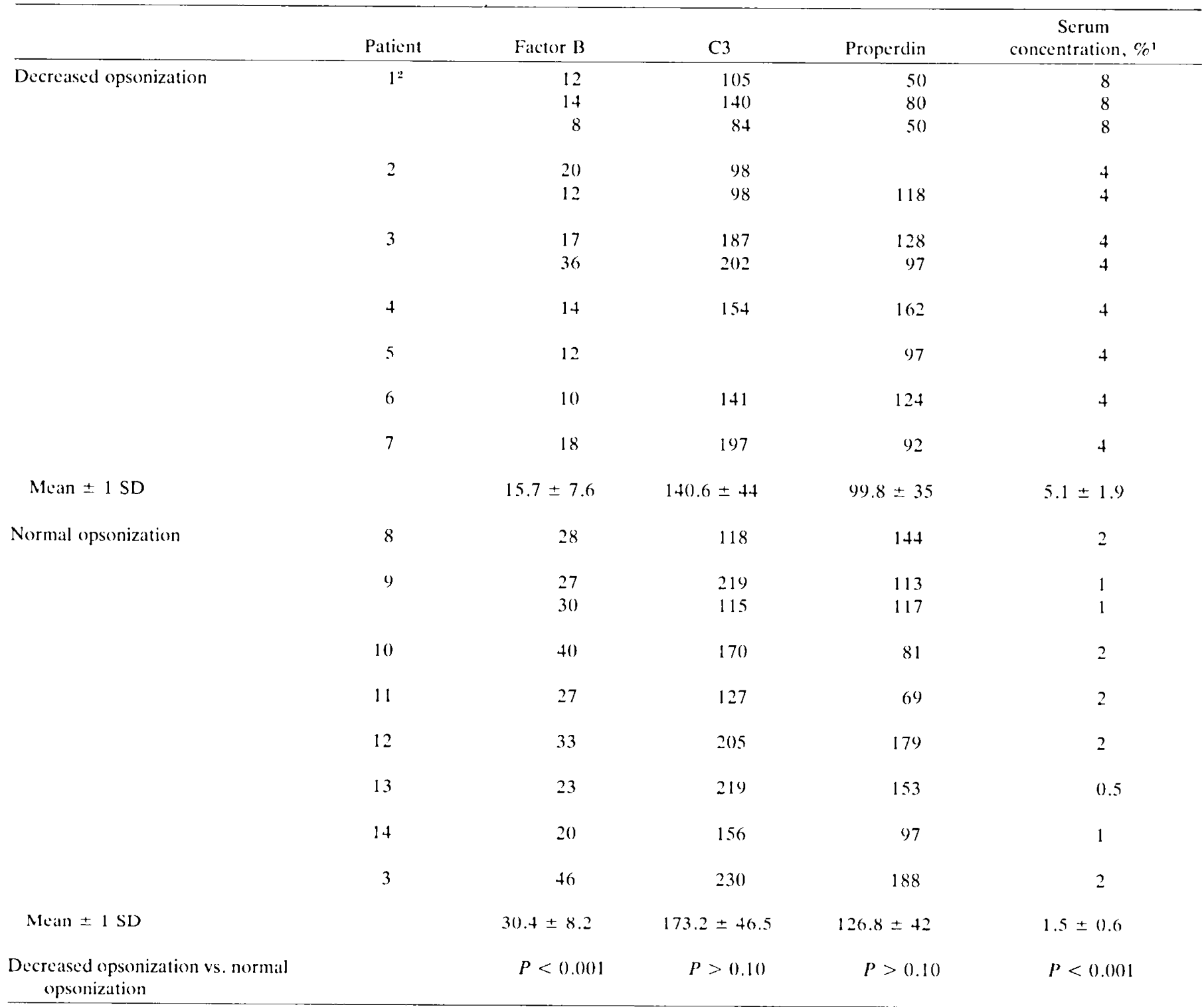

${ }^{1}$ Serum concentration (\%) which reduces $E$. coli by more than $80 \%$ in 2 hr.

2 Sepsis, Diplococcus pneumoniac.

ricidal activity for $S$. newport and $E$. coli, decreased chemotactic factor generation for normal polymorphonuclear cells and decreased phagocytosis of $D$. pneumoniae have been reported in patients with hypercatabolism of $\mathrm{C} 3(1,2)$.

Reconstitution of serum with factor $B$ did not always result in increased opsonization. Furthermore, opsonization was normal in the sera of some nephrotic patients despite reduced factor B levels. The opsonization defect in some nephrotic patients (such as in congenital nephrotic syndrome) may be the result of abnormalities of many serum proteins. Normal opsonization despite reduced factor $B$ levels may be due to higher serum concentrations of other alternative $C$ pathway components, as noted in patient 3 in Table 3 . It is also possible that these sera may have contained specific antibodies for E. coli and opsonization occurred via the classic pathway. Previous studies have suggested the importance of decreased serum IgG in opsonic deficiencies of immature newborn infants (6). Markedly reduced serum IgG levels, which occur regularly in the nephrotic syndrome (3), might explain deficient opsonization of $E$. coli in this syndrome. However, addition of $\operatorname{IgG}$ did not improve opsonic capacity of INS serum. Only 3 of 19 sera with markedly reduced factor $B$ concentration had abnormal opsonization of $S$. aureus $502 \mathrm{~A}$. These data support previous conclusions that certain strains of $S$. aureus are opsonized by the classic and not the alternative pathway.

The reduction in serum factor $B$ in this study is present in both steroid-responsive (or dependent) and steroid-resistant nephrotic patients. We do not know the cause of decreased serum factor $B$, but the pathologic finding of mesangial sclerosis or hypercellularity, a finding more commonly noted in steroidresistant nephrosis (4). does not appear to be of etiologic importance. The high correlation of serum factor $B$ with serum albumin concentration suggests that factor $B$, with a molecular weight of $80,000(10)$ compared to 69,000 for albumin, was being lost in the urine. We have demonstrated factor $B$ in the urine of nephrotic patients, but quantitative measurements have not been done (unpublished results). Immunofluorescent studies of renal biopsies for factor B show absence of glomerular cieposition. although tubular deposits are often noted. Studies of opsonic activity in sera from patients with systemic lupus erythematosus have demonstrated deficient opsonization for both $E$. coli and $S$. aureus (12). Decreased scrum factor $B$ was present and 
Table 3. Phagocytosis in idiopathic nephrotic syndrome sera using radiolabeled Escherichia coli-Effect of added factor B

\begin{tabular}{|c|c|c|c|c|c|}
\hline & \multirow[b]{2}{*}{$\mathrm{C} 3, \mathrm{mg} / 100 \mathrm{ml}$} & \multirow[b]{2}{*}{ Factor $\mathrm{B}, \mu \mathrm{g} \mathrm{N} / \mathrm{ml}$} & \multirow[b]{2}{*}{ Properdin, So of reference } & \multicolumn{2}{|c|}{ Phagocytosis of $E . c o l i^{1}$} \\
\hline & & & & $5 \%$ Serum & $5 \%$ Serum + factor $B$ \\
\hline Patient I & 143 & 10.4 & 140 & 60 & 98.5 \\
\hline Patient 2 & 135 & 11.2 & 147 & 56.5 & 87.0 \\
\hline Paticnt 3 & 200 & 12.8 & 197 & 93.0 & 86.0 \\
\hline Control & & & & 96 & 102 \\
\hline
\end{tabular}

1 Percentige of counts in leukocyte fraction after 20 min of incubation in phagocytosis assay using radiolabeled $E$. coli $022: H 16$.

factor $B$ was found to be necessary but, as in our studies, not completely sufficient for restoration of normal opsonization to all deficient sera. It was suggested that other alternative pathway components might also be depleted in active systemic lupus erythematosus.

Properdin is a serum euglobulin which can be activated in serum by endotoxin, zymosan, inulin, and other polysaccharides. It was considered possible that properdin participated in the opsonization of $E$. coli, but we detected no decrease in serum properdin concentration in the nephrotic patients examined, nor have we seen deposition of properdin on glomerular structures on renal biopsies when studied by immunofluoreseent methods.

\section{CONCLUSION}

Components of the classic pathway of complement activation (Clq, C4, C3) and alternative pathway factors (factor B, properdin) were measured in sera of patients with the idiopathic nephrotic syndrome of childhood. These sera were also assayed for opsonic activity against $E$. coli and $S$. aureus to determine whether there was correlation between this functional activity of serum and components of the complement system.

Serum factor $B$ was the only component which was significantly diminished in patients with idiopathic nephrotic syndrome when compared to normal patients $(P<0.001)$. There was a high correlation between levels of serum factor $B$ and serum albumin $) r=0.8(05, P<0.0(01)$. Se $r$ uential studies in 9 out of 10 patients confirmed that factor $B$ increased to normal levels with remission of INS. Serum properdin, Cly, C4, and C3 levels were not significantly decreased from normal in patients with INS.

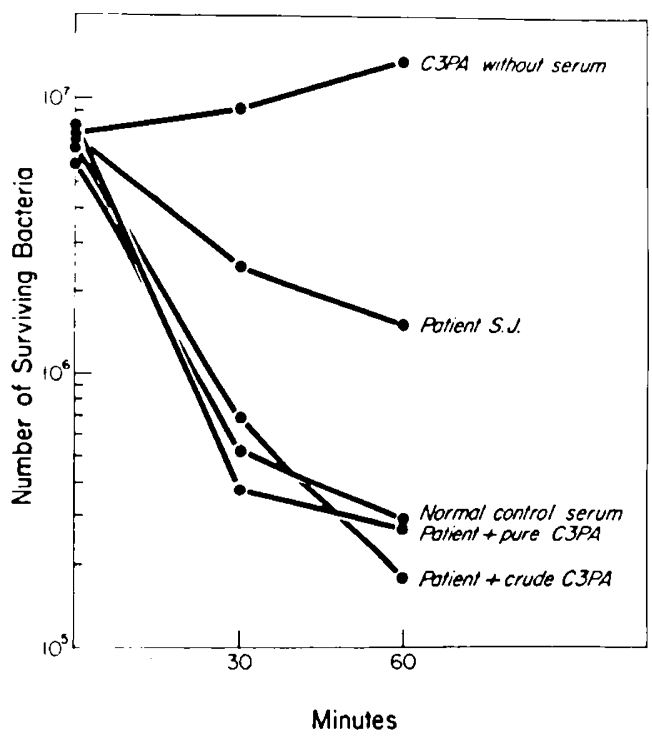

Fig. 3. Effect on opsonization of adding factor B (C3PA) to serum by bacterial killing test. The patient and control sera in a $1 \%$ concentration were simultaneously tested against Escherichia coli. The undiluted serum concentrations of factor $B$ of the patient was $18 \mu \mathrm{g} \mathrm{N} / \mathrm{ml}$. The final concentration of factor $B$ after addition of pure factor $B$ was $43 \mu \mathrm{g} \mathrm{N} / \mathrm{ml}$ and with crude factor $B$ was $53 \mu \mathrm{g} \mathrm{N} / \mathrm{ml}$.
Opsonization of $E$. coli was decreased in 11 of 20 sera from patients with active INS. The 11 sera with decreased opsonization of $E$. coli had a mean factor B level which was significantly below that for the 9 sera with normal opsonization. Serum opsonic activity for $E$. coli was restored to normal in 3 sera by the addition of isolated factor $B$. Opsonization of $S$. aureus was decreased in only 3 of 19 sera from patients with active INS.

The increased susceptibility to bacterial infections in some patients with INS may be due to decreased serum factor B levels but other predisposing factors, as yet undetermined, are also important.

\section{RIFERENCIS AND NOTES}

1. Alper, C. A., Abramson. N.. Johnston, R. B., Janol. J. H., and Rosen, F. S.: Increased susceptibility to infection associated with abmormalities of complement-mediated functions and of the third component of complement (C3). N. Engl. J. Med., 282: 349 (1970))

2. Alper, C. A., Bleck, K. J., and Rosen. F. S.: Increased susceptibility to infection in a patient with Type II essential hypercatabolism of C3. N. Engl. J. Med., 288: 601 (1973).

3. Barnett, H. L., and Shibuya, M.: Nephrosis in children. Postgrad. Med., 15: $362(1954)$.

4. Churg, J., Habib, R. R., and White, R. H. R.: Pathology of the nephrotic syndrome in children: A report of the International Study of Kidney Disease in Children. Lancet, $i$ : 1299 (1970).

5. Fowler, R.: Primary peritonitis: Changing aspects 1956-1970. Aust. Paediat. J., $7: 73$ (1971)

6. Forman, M. L., and Strehm, E. R.: Impaired opsonic activity but normal phagocytosis in low-birth weight infants. N. Engl. J. Med., 281: 926 (1969).

7. Gewurz, H., Page, A. R., Pickering, R. J., and Good, R. A.: Complement activity and inflammatory neutrophil exudation in man. Int. Arch. Allergy. 32: $64(1967)$.

8. Gewurz, H.. Pickering, R. J., Mergenhaten, S. E., and Good, R. A.: The complement profile in acute glomerulonephritis, systemic lupus erythematesus and hypocomplementemic chronic glomerulonephritis. Int. Arch. Allergy, 34: $556(1968)$.

9. Goodkofsky, I., and Lepow, I. H.: Functional relationship of Factor B in the properdin system to $\mathrm{C} 3$ proactivator of human serum. J. Immunol., 107: $1200(1971)$

10. Götze, O., and Müller-Eberhard, H. J.: The C3-activator system: An alternate pathway of complement activation. J. Exp. Med., 134: Suppl. 90 (1971).

11. Jasin. H. E.: Human heat labile opsonins: Evidence for their mediation via the alternate pathway of complement activation. J. Immunol., 109: 26 (1972)

12. Jasin, H. E., Orozeo, J. H., and Ziff. M.: Serum heat-labile opsonins in systemic lupus erythematosus. J. Clin. Invest.. 53: 343 (1974).

13. Johnston, R. B., Klemperer, M. R.. Alper, C. A. and Rosen, F. S. The enhancement of bacterial phagocytosis by serum. The role of complement components and two co-factors. J. Exp. Med., 129: 1275 (1969).

14. Johnston, R. B.. Newman. S. L., and Struth. A. G.: An abnormatity of the alternate pathway of complement activation in sickle cell disease. N. Engl. J. Med., 288: 8113 (1973)

15. Lewis, E. J.. Carpenter, C. B.. and Schur, P. H.: Serum complement components in human glomerulonephritis. Ann. Intern. Med., 75: 555 (1971).

16. Marcus, R. L., Shin, H. S., and Mayer, M. M.: An alternate component pathway: $\mathrm{C} 3$ cleaving activity, not due to $\mathrm{C} 42 \mathrm{a}$, on endotoxic lipopolysaccharide after treatment with guinea pig serum: Relation to properdin. Proc Natl. Acad. Sci. U. S. A., 68: 1351 (1971).

17. McLean, R. H., and Michacl, A. F., Properdin and C3 proactivator: Alernate pathway components in human glomerulonephritis. J. Clin. Invest., 52 $6.34(1973)$

18. Michael, A. F., McLean, R. H., Roy, L. P., Westberg, N. G., Hoyer, J. R. Fish, A. J., and Vernier, R. L.: Immunologic aspects of the nephrotic syndrome. Kidncy Int., 3: 105 (1973).

19. Norman, M. E., and Miller, M. E.: Spontancous chemotaxis in patients with glomerulonephritis and the nephrotic syndrome. J. Pediat., $83: 390$ (1973).

20. Peterson, P. K., Verhoef, J.. Suboth, L. D.. and Quie. P. G.: Extracellular and bacterial factors influencing staphylococcal phagocytosis and killing by human polymorphonuclear leukocytes. Infect. Immunity (In press).

21. Pickering, R. J., Michael, A. F., llerdman, R. C., and Good, R. A.: The 
complement system in chronic glomerulonephritis: Three newly associated aberrations. J. Pediat., 78: 30 (1971).

22. Pillemer, L., Blum, L., Lepow, 1. H., Ross, O. A., Todd, E. W.. and Wardlaw, A. C.: The properdin system and immunity. I. Demonstration and isolation of a new serum protein. Science, 120: 279 (1954).

23. Quie, P. G.. Messner, R. P.. and Williams, R. C. Jr.: Phagocytosis in subacute bacterial endocarditis: Localization of the primary opsonic site to the Fe fragment. J. Exp. Med., I28: 553 (1968)

24. Quie, P. G., White, J. G., Holmes, B., and Good, R. A .: In-vitro bactericidal capacity of human polymorphonuclear leukocytes: Diminished activity in chronic granulomatous disease of childhood. J. Clin. Invest., 46: 668 (1967).

25. Rowley, D., and Turner, K. J.: Number of molecules of antibody required to promote phagocytosis of one bacterium. Nature, $210 ; 496(1966)$.

26. Smith, M. R., and Wood, W. B., Jr.: Heat labile opsonins to pneumococcus. I. Participation of complement. J. Exp. Med., 130: 1209 (1969).

27. Stossel, T. P., Alper, C. A., and Rosen, I. S.: Opsonic activity in the newborn: Role of properdin. Pediatrics, 52: 134 (1973).

28. Winkelstein, J. A : Opsonins: Their function, identity and clinical significance.
J. Pediat 82: 747 (1973).

29. Winkelstein, J. A., Shin, H. S., and Wood, W. B.: Heat labile opsonins to pneumococeus. III. The participation of immunoglobulin and of the alternate pathway of $\mathrm{C} 3$ activation. J. Immunol., 108: 1681 (1972).

30. This work was presented in part at the Third International Symposium of Pediatric Nephrology, Washington. D.C.. September, 1974.

31. This research was aided by grants from the National Institutes of Health (AM12375, HE05662, HE06316, AI06931, and AI08821), The Kidney Foundation of the Upper Midwest. The Minnesota Medical Foundation and U.S. Army Contract DADA-17-70-C-0)(182.

32. The authors wish to express their sincere appreciation for the expert technical assistance of Kay Townsend, Barbara Roach, and Christine Windler and to Janice Alpin, Vince Berg, and Rita Rival for preparation of the manuscript and figures.

33. Requests for reprints should be addressed to: R. H. McLean, M.D.. Assistant Professor, University of Connecticut Health Center, Farmington, Conn. 06032 (USA).

34. Received for publication October 26, 1976

35. Accepted for publication January $14,1977$.

\title{
Hageman Factor and Disseminated Intravascular Coagulation (DIC) in Newborns and Rabbits
}

\author{
JAMES J. CORRIGAN, JR., ${ }^{(2)}$ ELSA J. SELL, AND CHERYL PAGEL \\ Department of Pediatrics, Sections of Hematology and Neonatal Biology, University of Arizona Health Sciences \\ Center, Tucson, Arizona, USA
}

\section{Summary}

There was no significant difference in the levels of factor XII between sick newborns and normal age-matched controls, although the levels of both groups were lower than normal older children. Detailed coagulation studies on 44 sick infants revealed 11 to have disseminated intravascular coagulation (DIC). In those with DIC, the mean Hageman factor was $20 \%$ and in those without DIC, $25 \%(P>0.05)$. Rabbits given a constant infusion of lysozyme (which inhibits factor XII) showed laboratory evidence of endotoxin-induced DIC. The data suggest that neither reduced factor XII levels nor Hageman factor inhibition provided protection from DIC. The data further suggest that other coagulation pathways might be involved in order to elicit the DIC.

\section{Speculation}

Since Hageman factor activation is thought to be involved in initiating the coagulation mechanism and activation of fibrinolytic, kinin, and complement systems and therefore may be involved in basic pathophysiologic reactions, this study was undertaken to determine whether physiologic reductions in this factor might be protective in any way. Although it was found that newborns had lower factor XII levels than older children or adults and that the levels were lower in the younger infants and were therefore thought to be due to a developmental delay, no protection from the development of acquired coagulopathies could be detected. A significant number of sick neonates were found to have a variant form of DIC (reduced plasma factors II,
V, VIII, and fibrinogen, but normal platelet counts instead of thrombocytopenia). It is speculated that these infants' platelets were not responsive to the DIC-provoking event due to a developmental platelet dysfunction.

The role of Hageman factor (coagulation factor XII) in activating the intrinsic or plasma coagulation mechanism is well known. More recently, factor XII has been reported to be involved directly or indirectly in activating the fibrinolytic, kinin, and complement systems $(7,19)$. Thus, it has been postulated that factor XII and its activation may play a pivotal role in the initiation of many pathophysiologic reactions ranging from inflammation to shock. Newborn infants are known to have reduced Hageman factor levels and normal adult levels are not achieved until $7-14$ days of age $(1,8)$. The biologic significance of this reduction in Hageman factor is not known.

Experimental and human data suggest that activation of factor XII may be instrumental in producing the coagulopathy of DIC (9-11). Pretreatment of rabbits with lysozyme, which prevents the activation of Hageman factor (16), reportedly protects the animals for developing liquoid-induced DIC (14). The purpose of this study was to investigate the levels of factor XII and their role in sick newborns with associated coagulopathies and to study the effect of factor XII inhibition on endotoxin-induced DIC in rabbits. The data indicate that neither reduced factor XII levels nor Hageman factor inhibition provided protection from DIC. The data also suggest that in both the experimental model and sick neonates another coagulation pathway must be involved in order to elicit the DIC. 